\title{
A Qualitative Study on the Contribution of the Choir to Social-Cultural and Psychological Achievements of Amateur Chorists
}

\author{
Gulnihal Gul ${ }^{1}$ \\ ${ }^{1}$ Department of Music Education, Uludag University, Bursa, Turkey \\ Correspondence: Gulnihal Gul, Department of Music Education, Uludag University, Bursa, Turkey. Tel: \\ 90-053-3553-9683. E-mail: gulnihalgul@gmail.com
}

Received: March 28, 2018

doi:10.5539/ies.v11n8p119

\begin{abstract}
A choir as a psychosocial and sociocultural phenomenon; makes important contributions to both music and to the general education of society through its educational and socialising features. With this research, it was aimed to determine the level of contribution of choir singing to social, cultural and psychological achievements of amateur chorists. As a result of the research, it has been found that choir singing contributes to the gaining of the habit of working together, to gaining in areas such as prestige and forming friendships, to develop ones worldview, to learn the cultural values of different countries, and to interiorize the cultural values of their own countries. In addition to this, it has been determined that the chorists participating in the choir work gain in achievements such as relaxation, happiness, peace, belonging, enthusiasm and, controlling ego, and it has also been found that choir affects the feelings of self-confidence and self-efficiency positively.
\end{abstract}

Keywords: amateur choir, chorists, social-cultural and psychological benefits

\section{Introduction}

Music, which is an organized behaviour made by people, made for people, is a social activity that aims at expressing the individual's feelings, experiences and thoughts (Erol, 2002, p. 32, Kaplan, 2005, p. 32). The choir which contributes to the culture and art lifestyle of society with its activities in this context, is a psychosocial and sociocultural phenomenon, and on the basis of this phenomenon lies the feature of being a social being. The choir is generally the most active and most prevalent musical ensemble in all societies with the reason that they can be formed easily and quickly (Uçan, 2001, p. 13; Çevik, 1997, p. 47).

Choir education, which is thought to have important contributions to the social, cultural and psychological achievements of individuals with their musical development, also contributes positively to both the musical culture and general education of society with its educational, instructive and socializing qualities not only in terms of chorists but also in terms of audiences (Egüz, 1981, p. 28; Gökçe, 2007, p. 325).

The common purpose of choirs, which contribute to the formation of individual, environmental-social, educational, psychosocial, cultural and economic functions and social cultures in human life and vary in their age groups and musical goals, is to sing together (Apaydın, 2007, p. 572; Yaşar, 2015, p. 14). Individuals who come together with a certain discipline understanding for this common purpose can gain many functions such as cooperation, grasping the necessity of democratic values within society, developing worldviews in national and international communication, acquiring socialising and organisational habits (Apaydın, 2001, p. 135; Apaydın, 2007, pp. 572-573; Sevinç, 2017, p. 229).

It is known that music is an important tool used in socializing; research shows that stress hormones are secreted less in the music-making individuals and the hormone oxytocin, which strengthens social ties and has a positive contribution to enhancing self-esteem and confidence, is produced more (Sar1, 2016, p. 24; Anshel \& Kipper, 1988; Bailey \& Davidson, 2003). In this context, a community with a foundational musical choir education, and being part of a choir, can be an important feature of an individual's physical and spiritual development.

When international studies on the cultural, social and psychological achievements of an individual's choral education are examined, it has been determined that the role of being choir member is positive in many aspects.

Beck, Cesario, Yousefi, and Enamoto (2000) aimed to determine the physiological effects of choir singing on the immune system in their study named "Impact of Choir singing and Stage Performance on Immunoglobulin and 
Cortisol Levels". For this purpose saliva samples of the chorists were taken; it was found that, the levels of immunoglobulin A increased by $150 \%$ during the study and $240 \%$ during the performances of the chorists; cortisol levels decreased by $30 \%$ during the study and increased $37 \%$ during their performances.

In their research, Bailey and Davidson (2003) found that homeless men singing in a choir had a positive turn in their social lives after joining the choir, and gained positive achievements in emotional, mental and social aspects. These results are parallel with Ruud's (1997) study in which he concluded that community-based musical activities have a therapeutic effect.

Bell (2004) found that there were 250,000 choirs in America and that Americans prefer to be a member of a choir more than any other artistic activitie.

Bonshor (2016) states that individuals, who sing in adult amateur choir ensembles, acquire values such as confidence and harmony, musical and moral support, mutual encouragement and mutual recognition.

Lamont, Murray, Hale and Katie Wright-Bevans (2017) conducted studies with adults who participated in a choir for more than four years: In their research they indicate that participation in artistic activities was important for social, physical and psychological benefits. As a result of the study, in which they indicated that musical success and social relations have great importance for the continuity of a choir, it was found that the individuals singing in a choir gained achievements such as self-investment, self-reward, a sense of belonging, joy of living, leadership and organizational skills.

It has been determined that in Turkey, there are studies on the rehabilitating effects of musical activities in terms of adult participation (Yener-Alkaya, 2011; Hasgül, 2016), but there are not enough studies on the contribution of choir singing to the physical and spiritual development of an individual. With this research, it was aimed to determine the level of contribution of the choir singing to social, cultural and psychological achievements of amateur chorists.

\section{Method}

In this section, information about sampling, design, and the data obtaining process of the research was given.

\subsection{The Research Design}

A qualitative research method was used in this study. Qualitative research is an interpretive research approach based on the examination of individuals in certain situations in their natural environment, aiming a realistic and holistic presentation of perceptions and events (Yıldırım \& Şimşek, 2006, p. 79; Christensen, Johnson, \& Turner, 2015, p. 54).

\subsection{The Research Group}

Typical case sampling was used in determining the sample group of the study. In typical sampling, the sample is formed with a typical sample from a large number of cases in the context of the research problem and it is intended to have an opinion on a specific area (Büyüköztürk, Kılıç-Çakmak, Akgün, Karadeniz, \& Demirel, 2014, p. 91; Yıldırım \& Şimşek, 2006, p. 81).

The interviews for the research were conducted face to face with 12 chorists belonging to a choir of an association. The demographic information of the surveyed chorists is shown in Table 1. 
Table 1. Findings of participants' demographic information

\begin{tabular}{lcc}
\hline Age & Average & Range \\
\hline & 54 & $26-80$ \\
\cline { 2 - 3 } & $\mathrm{f}$ & $\%$ \\
\cline { 2 - 3 } Gender & 8 & 66,7 \\
Female & 4 & 33,3 \\
Male & & \\
Marital Status & 8 & 66,7 \\
Married & 4 & 33,3 \\
Single & & \\
Educational Background & & - \\
Primary School & - & - \\
Secondary School & - & - \\
High School & 2 & 16.7 \\
Bachelor's Degree & 9 & 75 \\
Postgraduate & 1 & 8,3 \\
\hline
\end{tabular}

As seen in Table 1, It was detected that $66.7 \%$ of participant chorists are female, $33.3 \%$ are male, $66.7 \%$ are married, $33.3 \%$ are single, $8.3 \%$ are post graduate and $16.7 \%$ of them have received high school education and the average age was 54 .

\subsection{The Collection of Data}

The data of the research was collected by using a semi-structured interview technique chosen from interview technique types. In semi-structured interviews, the investigator may influence the flow of the interviewer depending on the flow of the interviewer's opinion. The researcher gives the interview the opportunity to respond to questions as he or she wants (Türnüklü, 2000, p. 547)

To obtain the research data, the researcher prepared a demographic information form containing the participants' age, gender, marital status and educational status and an interview form consisting of 5 open-ended questions. These questions were asked to three field specialists in order to obtain the validity, and in the opinion of experts, the final form for the application was asked.

\subsection{The Analysis of Data}

For the analysis of the data in which the demographic information is included, the mean, frequency and percentage calculations are used. Descriptive analysis techniques were used in analyzing the data obtained during the interview. Descriptive analysis often includes a direct citation to reflect the views of participants (Yildırım \& Şimsek, 2006, p. 224).

The data obtained from the study were coded, then separated by theme and interpreted. When the quotes were made, the names of the participants were coded as chorist 1 (K.1), chorist 2 (K.2).

To ensure the reliability of the study, the data was presented to two field experts and a consistency study was conducted. Consensus and disagreement have been identified by the result of research, and according to Çepni (2014), where in the reliability calculation formula P (Percent consistency) $=\mathrm{N}$ (number of the same item two encoded form) * $100 / \mathrm{Nt}$ (the number of substances in a form) are calculated. The agreement between experts' evaluations is 91.66. Since this value is considered to be sufficient to be 70 or above (Miles \& Huberman, 1994; actin: Head, 2014, p. 105), it is concluded that providing reliability for data analysis.

\section{Results}

Findings obtained from the answers given to the research questions by the chorists participating in the research can be found in this section.

Table 2 shows the coding of the "Positive Emotions" theme, which was obtained from the views of the chorists about the reasons for choir singing. 
Table 2. Participant views on the reasons for singing in the choir

\begin{tabular}{lllcc}
\hline Theme & Codes & Participants & $\mathrm{f}$ & $\%$ \\
\hline \multirow{5}{*}{ Positive Emotions } & Love of singing & P2, P4, P7, P9, P12 & 5 & 41.6 \\
& To associate with people with the same & P2, P 4, P 7, P 12 & 4 & 33.3 \\
& musical tastes & P 3, P 4, P8, P9, P10 & 5 & 41.6 \\
& Spiritual relaxation & P 3, P 4, P5, P6, P9 & 5 & 41.6 \\
& Cooperation & P1, P3, P4, P9, P10, P11 & 6 & 50 \\
\hline
\end{tabular}

$41.6 \%$ of chorists stated that they would like to sing in choir since they enjoy singing, $33.3 \%$; to be together with people who have the same musical tastes, $41,6 \%$; to relax from a spiritual angle, $41.6 \%$; since it was carried out with cooperation, while $50 \%$ for moral satisfaction. Some of the chorists' views on this theme are given below.

"A person has the ability to decide what is good and bad for themselves. Time is passing by and it needs to be evaluated well. I knew very well that singing in the choir was going to be good for me". (P1)

"I love to sing and it is good for my soul. Moreover, to do it within a group is a different pleasure". (P3)

"Singing comforts me. When we see that we are united in the same feeling as the chorists, my hopes for life are increased and I feel stronger. I am filled with beauty, I look more lovingly towards people walking on the street." (P4)

"Singing in choir a makes me feel that I am a part of a whole. So in other words the choir is for me, I am for the choir. Taking place in the choir literally requires cooperation". (P5)

Table 3 contains the coding for the "Social Benefit" theme from participant views on the social contribution of the choir.

Table 3. Participants' views on the social contribution of the choir

\begin{tabular}{lllll}
\hline Theme & Codes & Participants & $\mathrm{f}$ & $\%$ \\
\hline \multirow{4}{*}{ Social Benefit } & Prestige & P1, P5, P6, P7, P9, P10 & 6 & 50 \\
& Friendship & P1, P2, P3, P8, P9, P10, P11, P12 & 8 & 66.6 \\
& Easy Communication & P2, P4, P5 & 3 & 25 \\
& Socialising & P3, P4, P5, P6, P9 & 5 & 41.6 \\
\hline
\end{tabular}

It was found that $50 \%$ of the chorists stated that singing in a choir had a socially positive prestige, $66.6 \%$ stated that it contributed to their friendship relations, $25 \%$ stated that it help them to communicate better and $41.6 \%$ stated that it had positive contributions to their socialising. Some of the chorists' views on this theme are given below.

"Since I started singing in a choir, I observed that I am more comfortable within different groups of people and with my relationships with friends. We find ourselves in a nice conversations with many people at the places we went to for the concert. We raise the energy of the listeners with the songs we sing. We both socialize and contribute to our culture". (P4)

"Your social circle is expanded, so you communicate easily in every area of your life, that is, your communication ability is increasied". (P2,P5)

"My social circle has grown considerably. It gave me great ease in terms of my social solidarity and my contribution". (P9)

"You see that you have a place in the society. Your circle of your friends is expanding". (P10)

Table 4 contains the coding for the "Cultural Benefit" theme from the participant's views on the cultural contribution of the choir. 
Table 4. Participant's views on the cultural contribution of the choir

\begin{tabular}{lllll}
\hline Theme & Codes & Participants & $\mathrm{f}$ & $\%$ \\
\hline & Acquisition of musical knowledge & P5, P10 & 2 & 16.6 \\
& Being with people who have different & P5, P7, P8 & 3 & 25 \\
& views & & 2 & 16.6 \\
Cultural Benefit & P1, P5 & P5, P8, P10 & 3 & 25 \\
& Information sharing & P2, P3, P4, P5, P6, P9, P11, P12 & 8 & 66.6 \\
& Team work & Cultural nourishment &
\end{tabular}

It was found that $16.6 \%$ of the chorists stated that singing in a choir helped them to acquire musical knowledge from a cultural point of view, $25 \%$ stated that it helped them to come together with people with different views, $16 \%$ stated that it helped to share knowledge and $25 \%$ stated that it helped to build teamwork, and $66.6 \%$ said that they were culturally nourished. Some of the chorists' views on this theme are given below.

"I think that my note knowledge and my ability to sing polyphonic notes has improved. This makes me feel different from many people culturally. "(P10)

"The cultural interaction in the festivals we attend is positive. Not only the music, but also the manners and experiences of my friends from different cultures and age groups, allow me to evaluate and nurture myself ". (P5)

"Whether during rehersals or during a performance, if we can work as a team in sync with the chef in giving a good end result, then everything is ok". (P8)

"The cultural structure of each country is different. It is a great wealth to recognize the differences of the musical structures of different countries, to learn the values, emotions, lifestyles of people from different countries with their music and integrate them with our own values ". (P11)

"I am culturally nourished as a member of the choir. I follow the concerts regularly and I feel a great emptiness when I can not follow them. I read about music and get new information ". (P9)

Table 5 contains the coding for the "Psychological Benefit" theme from the participant's views on the psychological contribution of the choir.

Table 5. Participant's views on the psychological contribution of the choir

\begin{tabular}{lllll}
\hline Theme & Codes & Participants & $\mathrm{f}$ & $\%$ \\
\hline & Relaxation & P1,P2, P7,P8, P10,P11 & 6 & 50 \\
& Happiness & P3, P6, P7, P10 & 4 & 33.3 \\
& Serenity & P5, P7 & 2 & 16.6 \\
& Nourish the soul & P4, P5, P6, P12 & 4 & 33.3 \\
Psychological Benefit & P4, P6 & 2 & 16.6 \\
& Take control of the ego & P6, P7, P8, P9 & 4 & 33.3 \\
& Excitement & P1, P2, P3, P4, P8, P9 & 6 & 50 \\
& Sense of belonging & P2, P5, P9 & 3 & 25 \\
\hline
\end{tabular}

$50 \%$ of the chorists say that being a choir member relieves them psychologically, $33 \%$ of them say that it gives them hapiness, $16 \%$ state that it gives them peace, $33 \%$ state that it nourishes their soul, $16,6 \%$ say that it helps to enable them to take control of the ego, $33,3 \%$ of them say that rehersals and performances make them feel excited. In addition, $50 \%$ of the chorists feel that being a member of the choir ensures a feeling of belonging, and $25 \%$ stated that it has a positive impact on their self-confidence. Some of the chorists' views on this theme are given below.

"Being a chorist creates many feelings like comfort, happiness, belonging. Also every new song is a new journey and a new excitement". (P2)

"The chef brings the music together in a way that it is good for my soul and body. When I sing in the choir, I become the time, space, season, I become the world in short... It is good for me, it is an inevitable lifestyle". (P1)

"In a single sentance the choir protects the well being of my body and soul. I have either got rid of or got under control my stress-related issues created by business life. I look forward to the days when I go to the choir. I feel totally confident and as a result give assured performances". (P5) 
"It allows you to control the ego on the way to becoming a human being. The feeling of being part of a whole is good for the soul and my soul is nourished from the beauty of the choir." (P4)

"What makes life so good is that the effort you give is rewarding. Our rehearsals always remind me to make the earth ready for seeding and toss the seeds. I am excited to go to every rehearsal with these feelings. The performance is quite different. It is like the seedlings you have grown with great effort come to fruition and you feel the taste of that fruit. The happiness of this can not be described, of course. A person should definitely experience this feeling." (P6)

"Being a chorist is very special and beautiful. It is a great feeling to be a member of this great community that binds me to life”. (P9)

“Feeling like I'm still working makes me happy and makes me feel young.” (P12)

\section{Discussion}

In this study, the contributions of singing in an amateur choir in terms of social, cultural and psychological aspects were examined and it was concluded that many contributions were made in a positive direction.

It has been determined that, in the direction of the findings, the chorists prefer to sing in the choir with positive emotions such as love for singing, desire to be with people with the same taste of music, spiritual relaxation, cooperation, happiness and spiritual wealth. In addition, participants stated that being a chorist made them feel prestigious; they found that they started friendships more comfortably and quickly and it contributed positively to their socialising. It can be said that being a chorist with this aspect gives social benefits to the individuals. In similar studies, it is stated that the choir has many personal and social gains for the individuals (Adams, 2000, Bailey \& Davidson, 2002; Clift, Hancox, Morisson, Hess, \& Kreutz, 2010).

It has been found out that chorists got musical information by singing in a choir, increased not only their musical knowledge but only their cultural accumalation by interpreting and evaluating the views they acquaired by being with people having different opinions, gained team spirit and acter with this spirit in rehearsal and performances, were able to learn the cultural structures of different countries through music and to absorb cultural values of their own countries. In his study (2001), Okyay states that individuals are aware of their cultural values by singing in the choir and they have meaning in their lives. It is thought that the choir also influences individuals' self-efficacy (Bandura, 1995, p. 2) beliefs positively.

It has been determined that the chorists participating in the choir work have gained achievements such as relaxation, happiness, peace, belonging, enthusiasm, and control of the ego, and that the choir affects the individual's feelings of self-confidence and self-efficacy positively. Dursun et al. (2017) included musical activities in the choir in the music therapy project they performed in neurological rehabilitation applications and have found that patients' daily living activities, quality of life, social relations, and level of involvement were positively affected.

The following suggestions can be made in the framework of the results obtained:

As the easiest, most effective, and most economical educational tool, disseminated of choir music widely carries weight in order to get effective and fast results in the musical development of the society with the choir education which has important social, cultural and psychological gains for the individuals.

Choir provides great benefits in terms of educator, instructor and socializer; the individuals in choir strengthen their social successes in these communities and acquire acquisitions such as friendship, cooperation, communication and responsibility and they can make these gains throughout their lives (Yener, 2001, p. 84) For this reason, the number of cores that affect not only music culture of society but also general culture of it should be increased; these formations should be supported by governmental institutions and organizations as well as non-governmental organizations.

In recent years, music has been used considering its rehabilitative property in Turkey. However, especially the community based choir music should be treated with its physical and psychological healing features, studies to benefit from its therapeutic effect should be increased and choir education should be used for this purpose.

\section{References}

Adams, K. (2000). How can I keep from singing: A lifetime of sweet singing in the choir. Proceeding of the International Symposium Sharing the Voices: The Phenomenon of Singing 2 (s. 7-15). St. John's, Newfoundland: Canada: Memorial University of Newfoundland.

Anshel, A., \& Kipper, D. (1988). The Influence of Group Singing on Trust and Cooperation. Journal of Music 
Therapy, 145-155. https://doi.org/10.1093/jmt/25.3.145

Apaydın, M. (2001). Koro ile Müzik Eğitiminin Toplumun Müziksel Düzeyini Geliştirmedeki Yeri ve Önemi [The place and importance of choir and music education in developing the musical level of society ]. $I$. Ulusal Koro Eğitimi ve Yönetimi Sempozyumu (pp. 131-140). Ankara: Sevda Cenap And Müzik Vakfı.

Apaydın, M. (2007). Çocuk ve Gençlik Korolarının, Toplumun Kültürel Gelişimindeki Yeri ve Önemi [Children's and Youth Choir of the place and importance in the Community Cultural Development]. II. Ulusal Çocuk ve Gençlik Edebiyatı Sempozyumu (pp. 569-576). Ankara: Ankara Üniversitesi Basımevi.

Bailey, B. A., \& Davidson, J. W. (2003). Amateur Group Singing as a Therapeutic Instrument. Nordic Journal of Music Therapy, 18-33. https://doi.org/10.1080/08098130309478070

Bailey, D., \& Davidson, J. (2002). Adaptive characteristics of group singing: perceptions from members of a choir for homeless men. Musicae Scientiae, 6(2), 221-256. https://doi.org/10.1177/102986490200600206

Bandura, A. (1995). Exercise of personel and collective efficacy in changing socities (A. B. (Ed.), Dü.). New York: Cambridge University Press. https://doi.org/10.1017/CBO9780511527692

Baş, G. (2014). Lise Öğrencilerinde Yabancı Dil Öğrenme Kaygısı: Nitel Bir Araştırma [Foreign Language Anxiety in High School Students: A Qualitative Study]. Pamukkale Üniveristesi Eğitim Fakültesi Dergisi, 101-119.

Beck, R. J., Cesarı, T., Yousefi, A., \& Enamoto, H. (2000). Choral Singing, Performance Perception, Immune System Changes in Salivary Immunoglobulin A and Cortisol. Music Perception, 18(1), 87-106. https://doi.org/10.2307/40285902

Bell, C. L. (2004). Update on Community Choirs and Singing in the United States. International Journal of Research in Choral Singing, 2(1), 39-52.

Bonshor, M. (2016). Sharing knowledge and power in adult amateur choral communities: The impact of communal learning on the experience of musical participation. International Journal of Community Music, 9(3), 291-305. https://doi.org/10.1386/ijcm.9.3.291_1

Büyüköztürk, Ş., Kılıç-Çakmak, E., Akgün, Ö., Karadeniz, Ş., \& Demirel, F. (2014). Bilimsel Arştırma Yöntemleri[Scientific Research Methods]. Ankara: Pegem Akademi.

Christensen, L., Johnson, R., \& A. Turner, L. (2015). Araştırma Yöntemleri [Research Methods]. Ankara: Anı Yayıncilık.

Clift, S., Hancox, G., Morisson, I., Hess, B., \& Kreutz, G. (2010). Choral singing and psychological wellbeing: Quantitative and qualitative findings. Journal of Applied Arts and Health, 1(1), 19-34. https://doi.org/10.1386/jaah.1.1.19/1

Çepni, S. (2014). Araştırma ve Proje Çalışmalarına Girişs [Introduction to Research and Project Studies]. Trabzon: Celepler Matbaacıllk.

Çevik, S. (1997). Koro Eğitimi ve Yönetim Teknikleri[Choir Education and Conducting Techniques]. Ankara: Doruk Yayınevi.

Dursun, B. M., Akyel, S., Şen, S., Karaca, Ç., Çapa-Tayyare, B., Gökbel, T.,... Dursun, E. (2017). Türkiye’de Nörolojik Rehabilitasyon Kapsamında Bir Müzik Terapi Projesinin Geliştirilmesi [Development of a Music Therapy Neurological Rehabilitation within the Project in Turkey]. İstanbul Üniversitesi Eğitim Bilimleri Enstitüsü İstanbul Eğitimde Yenilikçilik Dergisi, 3(1), 77-83.

Egüz, S. (1981). Koro Eğitimi ve Yönetimi [Choir Education and Conducting]. Ankara: Ayyıldız Matbaası.

Erol, A. (2002). Bir Dönemin Popüler İkonu Olarak Zeki Müren [Zeki Müren as A Period Popular Icon]. (A. Yaraman, Dü.) İstanbul: Bağlam Yayınları.

Gökçe, M. (2007). 38. Uluslararası Asya ve Kuzey Afrika Çalışmaları Kongresi. Koro Müziğinin Toplumsal İşlevleri Açısından Türkiye Korolar Şenliğinin Kazandırışları Üzerine Genel Bir Değerlendirme[A General Evaluation on The Gains of The Turkish Chorus Festival in Terms of The Social Functions of Choir Music]. (pp. 325-352). Ankara.

Hasgül, E. (2016). Sosyal Hizmet Uygulamalarına Sanatın Önemi [The importance of art in social work practices]. International Journal of Innovative Research in Education, 3(2), 55-60. https://doi.org/10.18844/ijire.v3i2.998

Kaplan, A. (2005). Kültürel Müzikoloji[Cultural Musicology]. İstanbul: Bağlam Yayıncılık. 
Lamont, A., Murray, M., Hale, R., \& Wright-Bevans, K. (2017). Singing in later life: The anatomy of a community choir. Psychology of Music, 1-16.

Okyay, E. (2001). Ezgi'nin Serüveni ve Koro Kültürü Hakkında [About Melody's Adventure and Choir Culture]. I.Ulusal Koro Eğitimi ve Yönetimi Sempozyumu (pp. 57-66). Ankara: Sevda Cenap And Müzik Vakfı.

Ruud, E. (1997). Music and İdentity. Nordic Journal of Music Therapy, 6(1), 3-13. https://doi.org/10.1080/08098139709477889

Sarı, E. (2016). Müzik Ruhun Gidasıdır [Music is The Essence of The Soul]. Antalya: Net Medya Yayınc1lı.

Sevinç, S. (2017). Koro Eğitiminde Takım Çalışmasına Dayalı Öğrenmenin Önemi [The Importance Of Team-Based Learnıng In Choir Education]. NWSA Fine Arts, 228-234.

Türnüklü, A. (2000). Eğitimbilim Araştırmalarında Etkin Olarak Kullanılabilecek Nitel Bir Araştırma Tekniği: Görüşme [A Qualitative Research Technique to be Effectively Used in Educational Research: Interview]. Kuram ve Uygulamda Eğitim yönetimi Dergisi, 543-559.

Uçan, A. (2001). İnsan, Müzik, Koro ve Koro Eğitiminin Temelleri [Human, Music, Foundations of Education Choir and Chorus]. I. Ulusal Koro Eğitimi ve Yönetimi Sempozyumu (pp. 1-7). Ankara: Sevda-Cenap And Müzik Vakfi.

Yaşar, Y. (2015). Güzel Sanatlar ve Spor Liselerinde Koro Çalışmalarında Karşılaşılan Ses Eğitimi ile İlgili Sorunların Çözümüne Ilişskin Yaklaşımlar [Approaches To Solutıons To Problems In Voıce Trainıng In Choır Performances At Fine Arts And Sports High School] (Yayınlanmamış yüksek lisans tezi). Gazi Üniversitesi Eğitim Bilimleri Enstitüsü, Ankara.

Yener, S. (2001). Türkiye'deki Koro Çeşitleri ve Müzik Toplum Etkileşiminde Koro Müziğinin Rolü [Choir types in Turkey and the Role of Choir Music in Music and Community İnteraction]. I. Ulusal Koro Eğitimi ve Yönetimi Sempozyumu (pp. 83-94). Ankara: Sevda Cenap And Müzik Vakfi.

Yener-Alkaya, Y. (2011). Müziğin Çocuklar ve Yaşlılar Üzerindeki Etkileri [The Effects of Music on Children and the Elders]. Pamukkale Üniversitesi Eğitim Fakültesi Dergisi, 29, 119-124.

Yıldırım, A., \& Şimşek, H. (2006). Sosyal Bilimlerde Nitel Araştırma Yöntemleri[Qualitative Research Methods in Social Sciences]. Ankara: Seçkin Yayıncılık.

\section{Copyrights}

Copyright for this article is retained by the author(s), with first publication rights granted to the journal.

This is an open-access article distributed under the terms and conditions of the Creative Commons Attribution license (http://creativecommons.org/licenses/by/4.0/). 